\title{
Responses to orally ingested Neotyphodium endophyte toxins in laboratory animals
}

\author{
T. INOUE ${ }^{1}$ and H. KOBAYASHI ${ }^{2}$ \\ ${ }^{1}$ School of Food, Agricultural and Environmental Sciences, Miyagi University, Sendai, 982-0215, Japan \\ ${ }^{2}$ Faculty of Agriculture, Iwate University, Morioka, 020-8550, Japan
}

inoueta@myu.ac.jp

\begin{abstract}
A series of experiment were conducted to examine the toxicities of Neotyphodium endophyte in laboratory animals. Groups of mice and hamsters were fed endophytic perennial ryegrass seeds. The hamsters presented ergotism-like symptoms while mice hardly indicated the toxicosis. Goups of mice and hamsters were fed endophytic perennial ryegrass seeds for 8 days and total excreta collections were made to evaluate apparent absorptions of endophytic alkaloids. Accumulations of endophyte toxins in the tissues and organs were also analysed. Although approximately $50 \%$ of lolitrem B and $90 \%$ of ergovaline were absorbed by both species, and lolitrem B accumulation in the liver and fat tissues, only the hamsters showed mild tremors. A condensed lolitrem B fraction was orally administrated to mice and hamsters and total excreta collections were made. The mice were not affected by even large amounts of lolitrem B dosages with high absorptions $(>80 \%)$ when orally administrated.
\end{abstract}

Keywords: ergovaline, lolitrem B, toxicosis, mouse, hamster, endophyte

\section{Introduction}

Although the toxicity of the alkaloids ergovaline and lolitrem B that are produced by Neotyphodium endophytes to ruminants is generally well known, toxicity of these alkaloids, particularly lolitrem B for monogastric animals including humans, have not yet been established. A recent review from a pharmacokinetic point of view on ergotism in ruminants implicated ergoline alkaloids as major cause rather than ergot alkaloids such as ergovaline (Hill et al. 2005). On the other hand, lolitrem B, which is a powerful tremogenic substance for ruminants, can cause tremors in mice when it is administrated intra-peritonealy (Gallagher \& Hawkes 1986). However, there are few detailed reports of the tremogenic effects of orally administrated lolitrem

Figure 1 Changes in body weight of hamsters fed diets containing perennial ryegrass seeds with $(E P+)$ or without (EP-) endophyte infestation. ( ${ }^{* \star}$ indicates $\mathrm{P}<0.01$ )

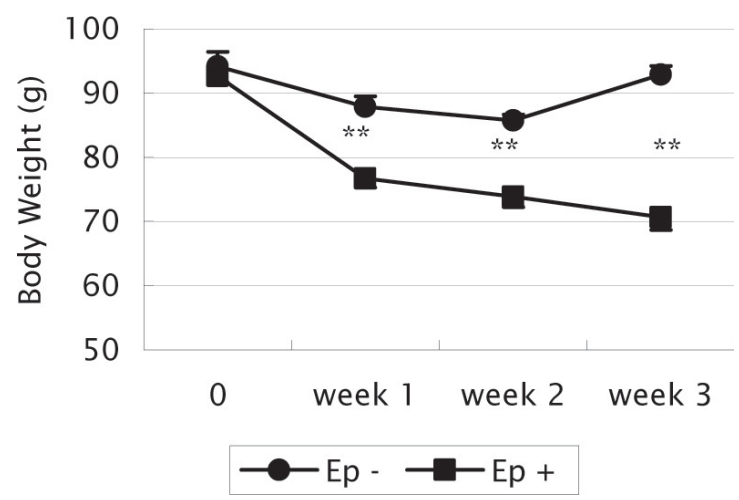

B or ingested endophytic grasses containing primarily lolitrem B on monogastric animals.

The endophytic symbiosis can bring agronomic advantages such as improved productivity and insect resistances for the hosting grasses but should also be safe for mammalian herbivores, especially livestock. Evidently the symbiotic interactions between the endophytes and hosting grasses are complex and there can be unrecognised or overlooked substances present, which may have adverse effects on animals. Tremogenic janthitrems found in an endophytic perennial ryegrass demonstrate this possibility (Tapper \& Lane 2004). This suggests that, safety of the grasses for livestock may not be determined simply by monitoring levels of ergovaline and lolitrem B and should rely more on bioassays that test oral ingestion of materials in orthodox laboratory animals. This preliminary study examined responses of laboratory animals to orally ingested endophytic grasses or alkaloids extracted from those grasses.

\section{Materials and Methods}

\section{Effects of ingesting endophytic grasses on hamsters and mice}

For the trial with hamsters, seeds of perennial ryegrass (Lolium perenne) infected with the wild-type Neotyphodium lolii endophyte were finely ground and mixed thoroughly with ground basal diet (60:40) (EP+). The mixture was compacted into small self-sustaining discs using a hydraulic press. The control diet was prepared in the same way except for using endophyte-free ryegrass seeds (EP-). Twelve 8-week-old female standard Syrian hamsters were individually caged and randomly allocated to two groups (EP+ hamsters and $\mathrm{EP}-$ hamsters) to receive one of the diets. The ambient temperature was set for $26^{\circ} \mathrm{C}$ and the hamsters were allowed to have access to the diet and water at any time. Each group was fed with the diet for 3 weeks after a 4 day adaptation period. Feed intake was recorded daily and body weight was measured weekly. A set of diets were similarly made with a different set of seeds for mice (seeds 70: basal diet 30). Thirty 8-week old female ddY mice were individually caged, randomly allocated to two groups (EP+ mice and EP- mice) and fed ad libitum for 32 days. The ambient temperature was $32^{\circ} \mathrm{C}$ (high temp) for the first 2 weeks and for $15^{\circ} \mathrm{C}$ (low temp) for the last 2 weeks. There were 4 days in between to allow the animals to adjust to the temperature change. Feed intake was recorded daily and body weight, skin and rectal temperatures were recorded every 3 days.

\section{Absorption and accumulation of alkaloids in hamsters and mice}

Ground endophytic perennial ryegrass seeds collected only endophyte-infected tillers infestation were mixed with ground basal diet (50:50). Three each of 8-week-old female ddY mice (mean body weight $33.2 \mathrm{~g}$ ) and Syrian hamsters (106.5 g) were individually caged and fed ad libitum with the diet for 12 days. Feed and water intakes were recorded and the excretions of 
Figure 2 Changes in body weight of mice fed diets containing perennial ryegrass seeds with $(E P+)$ or without (EP-) endophyte infestation ( ${ }^{*}$ indicates $\mathrm{P}<0.05$ )

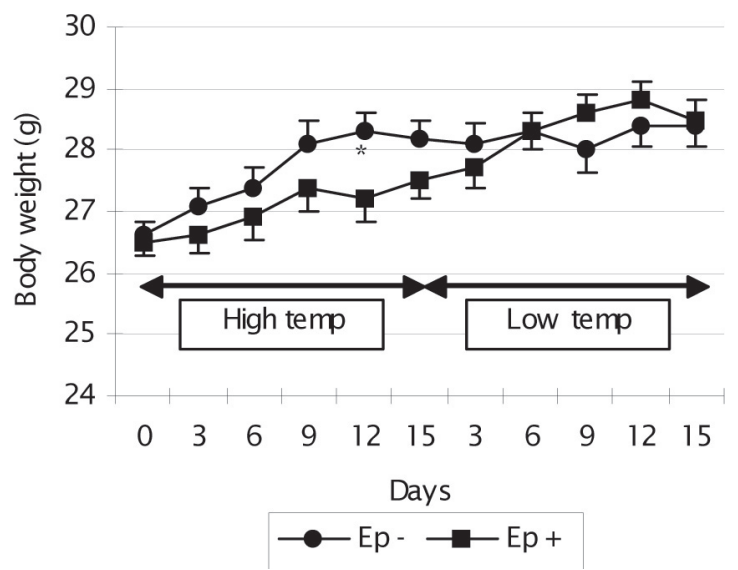

Figure 4 Accumulation of lolitrem $B$ in organs of laboratory animals fed endophyte infested perennial ryegrass seeds ( ${ }^{* *}$ indicates $\mathrm{P}<0.01$ ).

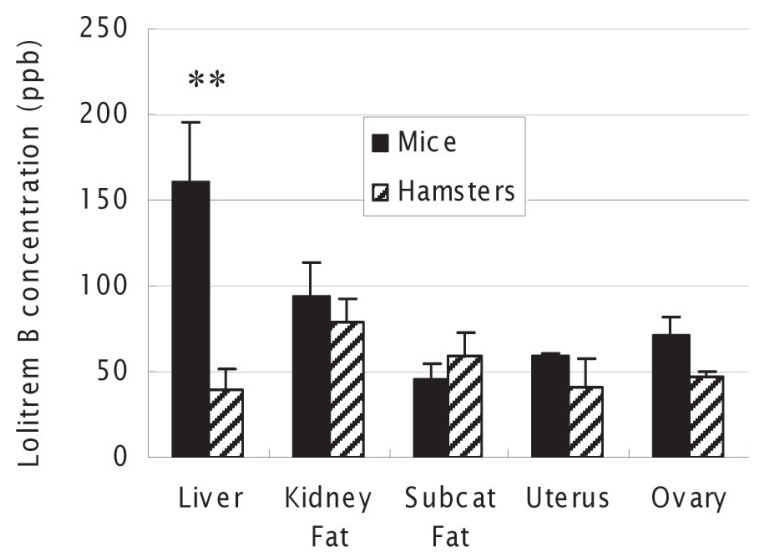

faeces and urine were separately pooled for the last 8 days. The animals were over-anaesthetised to euthanasia then dissected. Concentrations of ergovaline and lolitrem B were analysed in the diet, faeces, urine, liver, kidney fat, subcutaneous fat, uterus and ovary. It is assumed that proportions of the alkaloids that were not excreted into the faeces and urine were absorbed by the animals and absorptions of the alkaloids were calculated as proportions of the absorbed alkaloids to ingested alkaloids.

\section{Responses of mice and hamsters to orally administered} condensed lolitrem $B$ fractions

Finely ground endophyte infested perennial ryegrass seeds were immersed in a solvent (dichrolomethene 90: methanol 10) and gently shaken in darkness for $12 \mathrm{~h}$. The solvent was then filtered and evaporated completely in vaco and an oily fraction containing lolitrem B was obtained (lolitrem B fraction). Concentration of lolitrem B was $355.3 \mu \mathrm{g} / \mathrm{g}$ and a trace of ergovaline was found in the fraction. Nine 8-week-old standard Syrian hamsters (116.2 g) were allocated to three groups to receive one of the fractions containing $35.5 \mu \mathrm{g}$ (low), $78.2 \mu \mathrm{g}$ (medium) or $117.3 \mu \mathrm{g}$ (high)
Figure 3 Changes in skin and rectal temperatures of mice fed diets containing perennial ryegrass seeds with $(E P+)$ or without (EP-) endophyte infestation (* indicates $\mathrm{P}<0.05)$

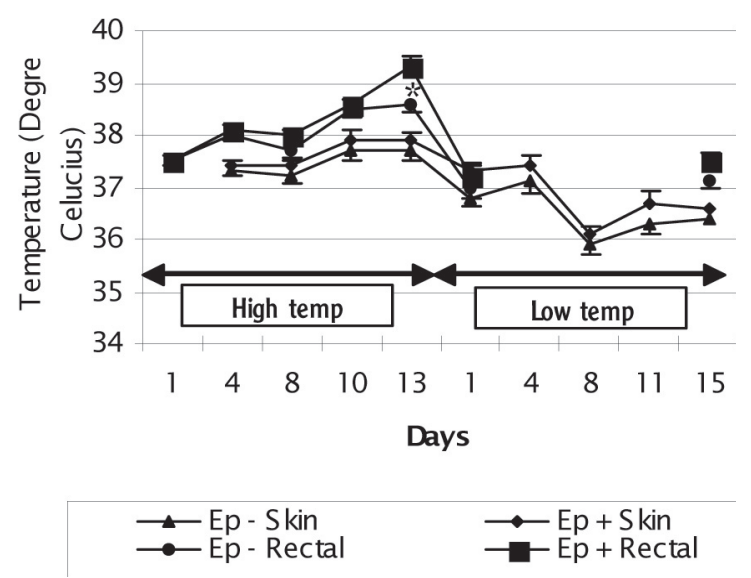

Figure 5 Changes in mean tremor score of the hamsters orally administrated with lolitrem $B$ fraction extracted from endophyte infected perennial ryegrass seeds.

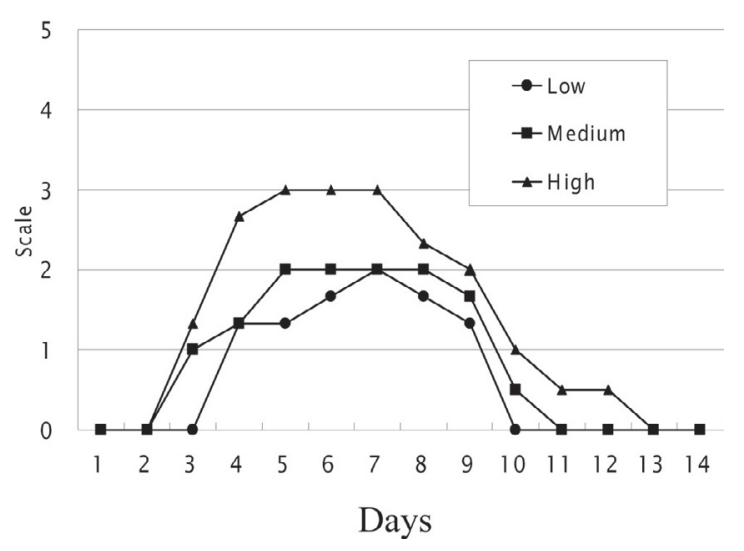

of lolitrem B. Similarly, groups of three 8-week-old ddY mice (32.1 g) each received fractions containing $21.3 \mu \mathrm{g}$ (low), $39.1 \mu \mathrm{g}$ (medium) or $56.9 \mu \mathrm{g}$ (high) of lolitrem B. The lolitrem B fractions were administrated directly into the stomach via a catheter for 8 days. Mouse chows and water were available to the animals all the time. Excretions of faeces and urine were collected daily. The animals were observed for tremor and intensity of tremor was scaled from $0=$ no tremor to $5=$ severe tremor according to Gallagher and Hawkes (1986).

\section{Analyses}

Ergovaline and lolitrem B were analysed by the partially modified method described by Barker et al. (1993) and Gallagher et al. (1986), respectively.

\section{Statistical analyses}

The data collected in the present study were subjected to t-test for statistical significances. 
Table 1 Estimated toxicity of lolitrem B in cattle and experimental animals.

\begin{tabular}{|c|c|c|c|c|c|c|c|}
\hline & Source & $\begin{array}{l}\text { Body } \\
\text { weight }\end{array}$ & $\begin{array}{l}\text { Feed } \\
\text { intake }\end{array}$ & $\begin{array}{l}\text { Lolitrem B } \\
\text { level }\end{array}$ & Absorption & $\begin{array}{c}\text { Lolitrem B } \\
\text { intake per } \\
\text { BW }\end{array}$ & Symptoms \\
\hline Cattle & Ep+grass & $600 \mathrm{~kg}^{1}$ & $20 \mathrm{~kg}^{1}$ & $1.8 \mathrm{ppm}^{2}$ & na & $\begin{array}{l}\text { Max.60 } \\
\mu \mathrm{g} / \mathrm{kg}^{3}\end{array}$ & + \\
\hline $\begin{array}{l}\text { Hamster } \\
\text { Mouse }\end{array}$ & $\begin{array}{l}\text { Ep+ } \\
\text { Seeds }\end{array}$ & $\begin{array}{l}107 \mathrm{~g} \\
33 \mathrm{~g}\end{array}$ & $\begin{array}{l}10.8 \mathrm{~g} \\
3.8 \mathrm{~g}\end{array}$ & $\begin{array}{l}12.3 \mathrm{ppm} \\
12.3 \mathrm{ppm}\end{array}$ & $\begin{array}{l}49.0 \% \\
55.3 \%\end{array}$ & $\begin{array}{l}1241 \mu \mathrm{g} / \mathrm{kg} \\
1416 \mu \mathrm{g} / \mathrm{kg}\end{array}$ & $\begin{array}{l}+ \\
-\end{array}$ \\
\hline $\begin{array}{l}\text { Hamster } \\
\text { Mouse }\end{array}$ & $\begin{array}{l}\text { LolitremB } \\
\text { fraction }\end{array}$ & $\begin{array}{l}116 \mathrm{~g} \\
32 \mathrm{~g}\end{array}$ & Oral dose & $\begin{array}{l}35.5 \mu \mathrm{g} / \text { day } \\
56.9 \mu \mathrm{g} / \text { day }\end{array}$ & $\begin{array}{l}\text { Approx.80\% } \\
\text { Approx.80\% }\end{array}$ & $\begin{array}{c}306 \mu \mathrm{g} / \mathrm{kg} \\
1778 \mu \mathrm{g} / \mathrm{kg}\end{array}$ & $\begin{array}{l}+ \\
-\end{array}$ \\
\hline
\end{tabular}

1:Estimated; 2:Aldrich-Markham et al. (2003); 3:If 100\% absorbed.

\section{Results}

\section{Effects of ingesting endophytic grass seed on hamsters and mice}

The diet for the hamsters contained $3.03 \mu \mathrm{g} / \mathrm{g}$ and $4.13 \mu \mathrm{g} / \mathrm{g}$ of ergovaline and lolitrem $\mathrm{B}$, respectively whereas these alkaloids were not contained in the control diet. The daily feed intake (mean \pm s.d.) of $\mathrm{EP}+$ and EP- hamsters was $6.05 \pm 1.25 \mathrm{~g}$ and $6.75 \pm 1.22 \mathrm{~g}$, respectively with no statistical significance. The EP+ hamsters lost more body weight compared with the EP- hamsters $(\mathrm{P}<0.01)$ throughout the period (Fig. 1). The concentrations of ergovaline and lolitrem B in the diet for the mice were $3.41 \mu \mathrm{g} /$ $\mathrm{g}$ and $11.41 \mu \mathrm{g} / \mathrm{g}$, respectively. The concentration of lolitrem B was rather high because the seeds used in this experiment were collected only from the tillers infected with endophyte and microscopic observation indicated that almost all the seeds had endophytic mycelia inside. Both groups of the mice consumed similar amounts of feed (EP- mice $3.64 \pm 0.29 \mathrm{~g}$ vs $\mathrm{EP}+$ mice $3.59 \pm 0.37 \mathrm{~g}$ ) during the high temperature period. During the low temperature period, feed intake increased to $4.82 \pm 0.27 \mathrm{~g}$ and $5.09 \pm 0.37 \mathrm{~g}(\mathrm{P}<0.05)$ for $\mathrm{EP}-$ and $\mathrm{EP}+$ mice, respectively. The EP+ mice had significantly $(\mathrm{P}<0.05)$ lower weight gain and elevated rectal temperature compared with the EP- mice during the high temperature period (Figs. $2 \& 3$ ). There was no significant difference between the groups during the low temperature period. During the low temperature period the rectal probe of the thermometer had mechanical problems and only initial and the final rectal temperatures were obtained. One of the $\mathrm{EP}+$ hamsters developed dry gangrene like regions in the hind legs and two others had redness, swelling and some small ulcers on their digits. No notable clinical signs or symptoms of toxicity were observed in the mice groups.

\section{Absorption and accumulation of alkaloids in hamsters and mice}

The diet contained $12.3 \mu \mathrm{g} / \mathrm{g}$ of lolitrem B and $12.9 \mu \mathrm{g} / \mathrm{g}$ of ergovaline. The hamsters and mice kept steady daily intake levels (hamsters $10.8 \mathrm{~g} / \mathrm{d}$ and mice $3.8 \mathrm{~g} / \mathrm{d}$ ). Apparent absorptions of ergovaline and lolitrem $\mathrm{B}$ by the mice were calculated as $55.3 \pm 3.50 \%$ and $95.3 \pm 0.46 \%$ and those by the hamsters were $49.0 \pm 1.38 \%$ and $89.9 \pm 1.13 \%$, respectively. The mice had higher absorptions for both alkaloids compared with those by the hamsters $(\mathrm{P}<0.05)$. While $0.1-0.2 \%$ of ergovaline was recovered from the urine, lolitrem $\mathrm{B}$ was not detected in urine. The highest accumulation of lolitrem B was found in the liver of the mice (Fig. 4) and lolitrem B tended to accumulate more in the organs of the mice than those of the hamsters $(\mathrm{P}<0.01$ for liver and $\mathrm{P}<0.05$ for ovary). Slight and occasional tremors were observed on the day 8 for some of the hamsters.
Responses of mice and hamsters to orally administered condensed lolitrem B fractions

Apparent absorptions of lolitrem B by the hamsters were $81.5 \pm 2.15 \%, 80.7 \pm 1.51 \%$ and $80.2 \pm 2.77 \%$ and by the mice $86.1 \pm 3.87 \%, 84.7 \pm 5.03 \%$ and $79.4 \pm 1.47 \%$ for the low, medium and high doses of the lolitrem $\mathrm{B}$ fraction, respectively. The hamsters started to show occasionally mild to moderate tremors, which corresponded to the different dosages, from day 2 of the experimental period (Fig. 5). Although the administration of the lolitrem B fraction was stopped, the tremors lasted up to 4 days. The mice, however, did not show any tremor, signs or symptoms which might indicate effects of the lolitrem B fraction.

\section{Discussion}

The hamsters clearly indicated compromised feed efficiencies and presented ergotism-like symptoms when fed diets containing endophyte-infected perennial ryegrass seed. The mice fed the diet containing $3.41 \mu \mathrm{g} / \mathrm{g}$ of ergovaline and kept at high temperatures had a reduced weight gain and elevated rectal temperature, which are typical symptoms of summer syndorome. The symptoms were, however, somewhat mild considering the ambient temperature was $32^{\circ} \mathrm{C}$. Almost identical results with rats were reported (Eichen et al. 2004) but the rats and the mice in the present study had taken ergovaline orally approximately 6 and 22 times the amount reported as the threshold for toxicosis in cattle (Aldrich-Markham et al. 2003).

The animals in the present study did not show any tremors or other obvious neurological disorders with lolitrem B at levels more than enough to cause ryegrass staggers in cattle and sheep. It was hypothesised that the reason for this was low absorption of the alkaloids from the diet in the gastro-intestinal tract. This was found not to be the case with high absorptions found for both mice and hamsters. The hamsters on the diet with $12.3 \mu \mathrm{g} / \mathrm{g}$ of lolitrem B showed slight tremors at the end but the mice were not at all affected by the alkaloids. Oral dosing demonstrated that the mice were extremely resistant to lolitrem B. Gallagher and Hawkes (1986) reported that mice had prolonged tremors when they were given an intra-peritoneal injection of lolitrem B at 500 $\mu \mathrm{g} / \mathrm{kg}$ which is still a high dosage.

\section{Conclusions}

Toxicity of lolitrem B for laboratory animals are summarised and compared with that of cattle in Table 1. Laboratory animals, especially mice, showed strong tolerance to the orally ingested endophytic alkaloids. Per unit body weight, the amount of absorbed lolitrem B that was toxic to hamsters was at least five 
times the toxic level for cattle while mice were not affected even at a level of almost 30 times that. This suggests that orally ingested lolitrem B might be powerfully metabolised in the liver of mice although this contradicts the high accumulation of lolitrem $\mathrm{B}$ in liver and fat tissues. Considering the strong tolerances of hamsters and mice towards ergovaline and lolitrem B, they may not be suitable for evaluation of safety of endophytic grasses.

\section{REFERENCES}

Aldrich-Markham, S.; Pirell, G..; Craig, A.M. 2003. Endophyte toxins in grass seed fields and straw. Pp. 1-4. In: Oregon State Univ. Extension Service EM 8598.

Barker, D.J.; Davis, E.; Lane, G.A.; Latch, G.C.M.; Nott, H.M.; Tapper, B.A. 1993. Effects of water deficit on alkaloid concentrations in perennial ryegrass endopyte associations. pp. 67-71. In: Proceedings of the 2nd International Symposium on Acremonium/Grass interactions. Eds. Hume, D.E.; Latch,
G.C.M.; Easton, H.S. Palmerston Nth, New Zealand.

Eichen, P.A.; Spiers, D.E.; Rottinghaus, G.E. 2004. Contribution of ergovaline to the fescue toxicosis response in rats. Poster 415 In: Proceedings of the 5th International Symposium on Neotyphodium/Grass Interactions. Eds. Kallenbach, R.; Rosenkrans, C. Jr.; Lock, T.R. Fayetteville, Arkansas.

Gallagher, R.T.; Hawks, A.D. 1986. The potent tremogenic neurotoxins lolitrem B and aflatrem: a comparison of the tremor response in mice. Experientia 42: 823-825.

Hill, N.S. 2005. Absorption of ergot alkaloids in the ruminant. pp. 271-290 In: Neotyphodium in Cool-Season Grasses. Eds. Roberts, C.A.; West, C.P.; Spiers, D.E. Blackwell, Ames, Iowa.

Tapper, B.A.; Lane, G.A. 2004. Janthitrems found in a Neotyphodium endophyte of perennial ryegrass. p 301 In: Proceedings of the 5th International Symposium on Neotyphodium/Grass Interactions. Eds. Kallenbach, R.; Rosenkrans, C. Jr.; Lock, T.R. Fayetteville, Arkansas. 